\title{
Penyuluhan Hukum Tentang Pemahaman Siswa SMA Terhadap Cyberbullying Dalam Perspektif Hukum Pidana Di SMAN 46 Jakarta Selatan
}

\author{
Lukman Hakim 1, * \\ ${ }_{1}^{1}$ Fakultas Hukum, Universitas Bhayangkara Jakarta Raya; Jl. Raya Perjuangan, Marga Mulya, \\ Bekasi Utara, Jawa Barat 17121. Telp: 021-88955882, 889955883, e-mail: \\ lukmanhakim33@gmail.com \\ * Korespondensi: e-mail: lukmanhakim33@gmail.com
}

\begin{abstract}
The increasing use of the internet on one hand provids a lot of convenience for human in carrying out their activities, but on the other hand it makes easier for certain parties to commit crime, in this case criminal act of defamation in the form of cyberbullying. While the majority of electronic media users are teenegers under the age of 18. Apart from the age aspect, this group is quite vulnerable to sorting out the content of the information they make because of their lack of understanding if the legal implication, especially criminal law which will ensnare them when the information they make is against criminal law. The Community Service Team of the Law Faculty of Bhayangkara University Jakarta Raya, took the intiative to conduct legal counseling to high school student who were in the youth category, especially at SMAN 46 South of Jakarta about the high school student' understanding of cyberbullying in the perspective of criminal law. Based on the phenomena above, this activity aims to make high school students able to understand cyberbullying in the perspective of criminal law, as well as understand the implications of criminal law for cyberbullying behavior, both in terms of victims and as perpetrators. The methodes of implementing this activity is carried out in several stages, starting from the preparation stage, the implementation stage, the evaluation of activities, untill the reporting of results. The results of the activities show increasing students' knowledge of the criminal law perspective of cyberbullying behaviour. The output produced from this activity is a pocket book as an additional reference about cyberbullying behaviour in the perspective of criminal law. In addition, the results of the activities are documented in the form of implementation reports and published in scientific journal in order to be able to provide the widest possible benefits in a formal and practical level.
\end{abstract}

Keywords: student, cyberbullying, criminal law

\begin{abstract}
Abstrak
Meningkatnya penggunaan internet di satu sisi memberikan banyak kemudahan bagi manusia dalam melakukan aktivitasnya, namun di sisi lain memudahkan bagi pihak-pihak tertentu untuk melakukan tindak pidana, dalam hal ini adalah tindak pidana pencemaran nama baik dalam bentuk cyberbullying. Sementara mayoritas pengguna media elektronik adalah kalangan remaja yang berusia di bawah 18 tahun. Selain dari aspek usia, kalangan ini cukup rentan untuk memilah isi dari informasi yang dibuatnya disebabkan kurangnya pemahaman mereka terhadap implikasi hukum, terutama hukum pidana yang akan menjerat mereka manakala informasi yang dibuatnya bersifat melawan hukum pidana. Tim Pengabdian kepada masyarakat Fakultas Hukum Universitas Bhayangkara Jakarta Raya berinisiatif untuk melakukan penyuluhan hukum kepada siswa SMA yang masuk kategori kalangan remaja, khususnya di SMAN 46 Jakarta Selatan tentang pemahaman siswa SMA terhadap cyberbullying dalam perspektif hukum pidana. Berdasarkan fenomena tersebut di atas, kegiatan ini bertujuan agar siswa SMA dapat memahami cyberbullying dalam perspektif hukum pidana, serta memahami implikasi hukum pidana dari perilaku cyberbullying, baik dari sisi sebagai korban maupun sebagai pelaku. Metode pelaksanaan kegiatan ini dilakukan dengan beberapa tahapan, dimulai dari tahap persiapan, tahap pelaksanaan, evaluasi kegiatan, hingga pelaporan hasil. Hasil kegiatan
\end{abstract}


menunjukkan meningkatkan pengetahuan siswa akan perspektif hukum pidana dari perilaku cyberbullying. Luaran yang dihasilkan dari kegiatan ini adalah buku saku sebagai tambahan referensi tentang perilaku cyberbullying dalam perspektif hukum pidana. Di samping itu, hasil kegiatan didokumentasikan dalam bentuk laporan pelaksanaan dan dimuat dalam jurnal ilmiah agar bisa memberikan manfaat seluas-luasnya secara akdemis dan tataran praktis.

Kata Kunci: siswa, cyberbullying, hukum pidana

\section{Pendahuluan}

Era globalisasi yang kita lalui menjadi tanda perkembangan teknologi itu sendiri. Globalisasi telah menjadi pendorong lahirnya era perkembangan teknologi Informasi Pesatnya perkembangan teknologi informasi menyebabkan perubahan secara cepat. Sedikit demi sedikit media sosial dapat mengikutsertakan masyarakat ke dalam suatu pola budaya yang baru dan dapat menentukan pola pikir serta budaya dan perilaku dalam masyarakat. (Suharyanto, 2013).

Segala bentuk perubahan dalam struktur sosial sangat memengaruhi pola hidup individu dalam masyarakat kontemporer ini. Melalui media elektronik dapat mengarahkan khalayak ke arah perilaku propososial ataupun antisosial (Sunarto, 2012). Namun, dampak yang paling besar pengaruhnya pada kaum remaja, karena usia ini merupakan periode transisi dalam kehidupan batiniah yang dapat membuat sangat labil kejiwaannya dan mudah dipengaruhi oleh rangsangan eksternal (Kartono, 2013).

Media elektronik atau yang lebih dikenal oleh masyarakat dengan nama media sosial (medsos) merupakan salah satu bentuk kemajuan teknologi informasi dan komunikasi. Melalui media sosial yang semakin banyak berkembang memungkinkan informasi menyebar dengan mudah di masyarakat. Informasi dalam bentuk apa pun dapat disebarluaskan dengan mudah dan cepat sehingga memengaruhi cara pandang, gaya hidup, serta budaya suatu bangsa. Melalui media sosial, manusia diajak berdialog, mengasah ketajaman nalar dan psikologisnya dengan alam yang hanya tampak pada layar, namun sebenarnya mendeskripsikan realitas kehidupan manusia. Namun, tidak disangkal bahwa pesan-pesan yang ditayangkan melalui media elektronik dapat mengarahkan khalayak, baik ke arah perilaku prososial maupun antisosial (Sunarto, 2012).

Sebagai bagian dari media sosial, Facebook dan Twitter menjadi pilihan mayoritas pengguna jejaring sosial, khususnya remaja sebab banyak layanan fitur yang ditawarkan dengan menarik. Sekitar $53 \%$ dari total pengguna facebook di Indonesia adalah remaja berusia di bawah 18 tahun. Sebuah riset yang dilakukan situs jejaring sosial Yahoo di Indonesia melaporkan, bahwa pengguna terbesar internet di Indonesia adalah remaja berusia 15-19 tahun yaitu sebesar 64\% (www.hukumonline.com, 5 Juli 2013). Dari laporan in.techradar dan linkedin.com yang melaporkan, bahwa jumlah pengguna jejaring sosial melalui Facebook di tahun 2017, Indonesia memiliki pengguna jejaring sosial terbesar keempat di dunia dengan jumlah mencapai 111.000 .000 pengguna. Amerika Serikat masih memimpin dengan 219.000.000 pengguna, disusul India mencapai 213.000.000 pengguna dan Brazil mencapai 123.000.000 pengguna. 
Sekarang ini memang banyak penyedia situs berbasis sosial network. Dengan potensi jumlah pengguna yang besar di jejaring sosial, sewajarnya jika dimanfaatkan dengan bijaksana untuk mendistribusikan segala konten atau informasi dari media yang sedang dibangun. Sebab pada dasarnya jejaring sosial selain memberikan kemudahan dalam berkomunikasi dan berinteraksi dengan baik dengan lingkungan sosial, juga memberikan kesempatan kepada remaja untuk belajar sehingga tidak gagap teknologi, di samping itu dapat mempercepat maturity (kedewasaan jiwa) remaja, apabila digunakan dengan bijaksana.

Pola jejaring sosial yang negatif dapat terjadi, sebagai contoh anggota jejaring sosial dapat terlalu kritis atau menuntut satu sama lain, atau anggota jejaring sosial dapat memperkuat atau mendorong pelaku yang membahayakan atau antisosial (Robert dan Gilbert, 2009). Tidak jarang komunikasi melalui jejaring sosial menuai problematika, sehingga berujung di meja hijau. Roberts mengatakan bahwa ini dikarenakan perilaku yang memang ada di dunia nyata dengan lebih mudah lagi ditransaksikan di dunia maya (Juju dan Sulianta, 2010). Banyak terjadi penyalahgunaan dari situs-situs tersebut. Munculnya beberapa kasus terkait penyalahgunaan jejaring sosial marak terjadi, salah satunya adalah cyberbullying.

Cyberbullying adalah perlakuan kasar yang dilakukan oleh seseorang atau sekelompok orang, menggunakan bantuan alat elektronik yang dilakukan berulang dan terus menerus pada seorang target yang kesulitan membela diri (Smith dkk, 2008). Dalam konteks hukum pidana, Cyberbullying dapat dikualifikasi sebagai suatu perbuatan yang melawan hukum pidana sesuai dengan ketentuan yang terdapat di dalam Kitab Undang-Undang Hukum Pidana (KUHP) dan Undang-Undang Nomor 18 Tahun 2008 sebagaimana telah diubah dengan Undang-Undang Nomor 19 Tahun 2016 tentang Informasi dan Transaksi Elektronik (Undang-Undang ITE)

Sebagai ilustrasi asus, terdapat seorang anak remaja berusia 18 tahun divonis bersalah oleh pengadilan Bogor karena dianggap menghina temannya lewat jejaring sosial facebook. Pada tahun 2010, Nurarafa alias Farah (18 tahun) terdakwa kasus penghinaan melalui situs jejaring sosial facebook dijatuhi vonis dua bulan 15 hari dengan masa percobaan selama lima bulan oleh hakim di Pengadilan Negeri Bogor. Dalam perkara tersebut, Ferly Fandini sebagai korban melaporkan penghinaan atas dirinya yang dilakukan oleh Nurarafah alias Farah. Saat itu Farah mengaku cemburu atas kedekatan pacarnya (Ujang) dengan pelapor (korban), sehingga Farah menulis kata-kata hinaan dalam facebook-nya (Widodo, 2013).

Dari ilustrasi kasus di atas, dapat dipahami bahwa meningkatnya penggunaan internet di satu sisi memberikan banyak kemudahan bagi manusia dalam melakukan aktivitasnya, namun di sisi lain memudahkan bagi pihak-pihak tertentu untuk melakukan tindak pidana, dalam hal ini adalah tindak pidana pencemaran nama baik.

Pencemaran nama baik melalui media sosial ataupun media elektronik merupakan perbuatan pidana sebagaimana yang diatur dalam Pasal 310 ayat (1) KUHP sebagai genus delict, namun oleh karena dilakukan dengan menggunakan media elektronik, maka diatur dalam Pasal 27 ayat (3) Undang-Undang ITE, akibatnya kedua ketentuan tersebut tidak dapat dipisahkan satu sama lain. Unsur pidana dalam kedua pasal tersebut yang kemudian dijadikan 
dasar untuk mengkualifikasi apakah suatu perkara pencemaran nama baik yang terjadi berimplikasi terhadap perbuatan pidana.

Berdasarkan data dari Southeast Asia Freedom of Expression Network (SAFEnet), sepanjang 2016 ada lebih dari 200 pelaporan ke polisi atas dasar tuduhan pencemaran nama baik, penodaan agama, dan ancaman, yang berbasiskan UU ITE. SAFENET juga mencatat munculnya 4 (empat) pola pemidanaan baru yaitu: aksi balas dendam, barter hukum, membungkam kritik dan terapi kejut yang sangat berbeda, jika tidak dapat disebut menyimpang dari tujuan awal ketika UU ITE dibentuk.

Undang-Undang Nomor 18 Tahun 2008 sebagaimana telah diubah dengan UndangUndang Nomor 19 Tahun 2016 tentang Informasi dan Transaksi Elektronik (UU ITE) dinilai tak jauh beda dengan undang-undang sebelumnya. Di mana terbitnya revisi Undang-Undang ITE ini menuai kritikan dari kalangan aktivis yang kerap menyuarakan kebebasan berekspresi, seperti Institute for Criminal Justice Reform (ICJR). Mereka menilai materi Undang-Undang ITE yang baru ini tidak berbeda jauh dengan Undang-Undang ITE sebelumnya yang seolah mengekang kebebasan berpendapat. Awalnya, Undang-Undang ITE ini diarahkan meningkatkan ekonomi Indonesia yang mengatur semua transaksi di dunia maya (ecommerce). Namun, seiring berkembangnya teknologi di media sosial, justru beberapa pasalnya dianggap merugikan karena cukup banyak orang yang dilaporkan ke polisi dan dijadikan tersangka pencemaran nama baik, sehingga cenderung mengancam kebebasan setiap orang berpendapat.

Jika dilihat dengan seksama, memang ketentuan pemidanaan mengenai perilaku bullying (merundung) di dunia siber (cyberbullying) yang diatur Pasal 45B Undang-Undang ITE potensial jauh lebih buruk ketimbang penerapan Pasal 27 ayat (3) Undang-Undang ITE. Sebab, hingga saat ini, Indonesia belum memiliki definisi baku terkait dengan perundungan (bullying) di dunia nyata. Namun, Undang-Undang ITE justru "memaksa" memberikan pengertian baku perundungan di dunia maya.

Pasal 45B Undang-Undang ITE menyatakan:

"Setiap Orang yang dengan sengaja dan tanpa hak mengirimkan Informasi Elektronik dan/atau Dokumen Elektronik yang berisi ancaman kekerasan atau menakut-nakuti yang ditujukan secara pribadi sebagaimana dimaksud dalam Pasal 29 dipidana dengan pidana penjara paling lama 4 (empat) tahun dan/atau denda paling banyak Rp750.000.000,00 (tujuh ratus lima puluh juta rupiah)."

Dari definisi ketentuan Pasal 45B Undang-Undang ITE di atas, secara implisit dapat dipahami dengan memasukan cyberbullying dapat menimbulkan overkriminalisasi. Sementara itu banyak ahli pidana dan negara-negara lain mengalami kesulitan merumuskan pengertian perundungan (bullying). Dikhawatirkan, tindak pidana ini berpotensi besar disalahgunakan dalam penegakannya. Dengan begitu, terbukalah celah pemberangusan kebebasan berekspresi di dunia maya. Hal ini sejalan dengan pandangan dari Douglas Husak yang menyatakan "too much punishment, too many crimes" (Husak, 2008). Suatu keadaan yang 
menurutnya telah melingkupi negara-negara di dunia, termasuk negara demokrasi besar seperti Amerika Serikat. Artinya, dengan masuknya tindak pidana baru ini disertai Pasal 27 ayat (3) tentang defamasi dunia maya ini, jelas Undang-Undang ITE terbaru ini masih berpotensi mengancam kebebasan berekspresi di Indonesia.

Ketentuan yang terdapat dalam Pasal 27 ayat (3) jo Pasal 45 ayat (1) Undang-Undang ITE tampak sederhana bila dibandingkan dengan pasal-pasal penghinaan dalam KUHP yang lebih rinci. Oleh karena itu, penafsiran Pasal 27 ayat (3) Undang-Undang ITE harus merujuk pada pasal-pasal pencemaran nama baik dan penghinaan dalam KUHP, oleh karena di dalam Undang-Undang ITE itu sendiri tidak terdapat pengertian tentang pencemaran nama baik. Dengan merujuk Pasal 310 ayat (1) KUHP, pencemaran nama baik diartikan sebagai perbuatan menyerang kehormatan atau nama baik seseorang dengan menuduhkan sesuatu hal yang maksudnya terang supaya hal itu diketahui umum. Perumusan Pasal 27 ayat (3) UndangUndang ITE menyatakan bahwa: "Setiap orang dengan sengaja dan tanpa hak mendistribusikan dan/atau mentransmisikan dan/atau membuat dapat diaksesnya informasi elektronik dan/atau dokumen elektronik yang bermuatan penghinaan dan/atau pencemaran nama baik". Sedangkan menurut Pasal 310 ayat (1) KUHP menyatakan: "Barang siapa sengaja menyerang kehormatan atau nama baik seseorang dengan menuduhkan sesuatu hal, yang maksudnya terang supaya hal itu diketahui umum, diancam karena pencemaran dengan pidana penjara paling lama sembilan bulan atau pidana denda paling banyak empat ribu lima ratus rupiah". Sementara terkait dengan ketentuan pemidanaan pencemaran nama baik dalam Undang-Undang ITE diatur dalam Pasal 45 Ayat (1).

Ketentuan Pasal 27 ayat (3) Undang-Undang ITE tidak dapat dipisahkan dengan norma hukum pokok Pasal 310 dan Pasal 311 KUHP sebagai genus delict, yang mensyaratkan adanya pengaduan. Tegasnya Pasal 27 ayat (3) Undang-Undang ITE adalah delik aduan. Hal ini sebagaimana terdapat dalam Putusan Mahkamah Konstitusi (MK) Nomor 50/PUU-VI/2008. Adapun yang dituju sebagai korban adalah orang (naturlijk person) bukan badan hukum (recht person). Dengan demikian, sudah seharusnya jika ada laporan tindak pidana tanpa adanya aduan dari korban berupa badan hukum (recht person) termasuk tetapi tidak terbatas berupa orang (naturlijk person) yang bukan pihak yang mengalami langsung pencemaran nama baik sesuai pasal dimaksud terkait pencemaran nama baik berdasarkan Pasal 27 ayat (3) jo Pasal 45 ayat (3) Undang-Undang ITE, maka sedari awal patut untuk dikesampingkan oleh penyidik.

Berdasarkan uraian tersebut diatas, pengabdi berupaya agar kegiatan pengabdian masyarakat ini dapat memberikan kontribusi bagi siswa di Sekolah SMAN 46 Jakarta adalah dapat menjadikan siswanya menjadi lebih memahami makna dan implikasi hukum pidana dari cyberbullying. Di samping itu agar siswa Sekolah SMAN 46 Jakarta dapat menginfomasikan pendidikan tentang tindak pidana cyberbullying bagi rekan-rekannya yang belum memahami pendidikan tentang tindak pidana cyberbullying. 


\section{Metode Pelaksanaan}

Kegiatan Pengabdian Kepada Masyarakat (PKM) dilaksanakan pada waktu yang bersamaan dengan pelaksanaan Kuliah Kerja Mahasiswa (KKM) Mahasiswa Fakultas Hukum Universitas Bhayangkara Jakarta Raya, bertempat di SMAN 46 Jakarta yang beralamat di Jl. Mesjid Darussalam Blok A, Kebayoran Baru, Jakarta Selatan, DKI Jakarta, pada hari Selasa, tanggal 05 November 2019.

Adapun kegiatan pengabdian kepada masyarakat ini dilaksanakan dalam beberapa tahapan sebagai berikut: Pertama, Tahap Persiapan, meliputi: a). Kegiatan survey lokasi pengabdian kepada masyarakat, yaitu SMAN 46 Jakarta Selatan, b). Permohonan ijin kepada Kepala Sekolah SMAN 46 Jakarta Selatan untuk pelaksanaan pengabdian kegiatan pengabdian kepada masyarakat, c). Penyelesaian administrasi, d). Pengadaan alat dan bahan., e). Persiapan akhir tempat untuk kegiatan penyuluhan. Kedua, Kegiatan penyuluhan hukum, meliputi: a). Pembukaan dan perkenalan dengan siswa dan pimpinan SMAN 46 Jakarta Selatan, b). Pelaksanaan pre-test terkait materi penyuluhan tentang pemahaman siswa SMA terhadap cyberbullying dalam perspektif hukum pidana, c). Sesi diskusi dan tanya jawab interaktif dengan siswa peserta penyuluhan. Ketiga, Penutupan kegiatan, meliputi: a). Pelaksanaan post-test untuk mengetahui tingkat keberhasilan penyuluhan, b). Sesi foto bersama dengan seluruh peserta penyuluhan dan jajaran SMAN 46 Jakarta Selatan dan mahasiswa Fakultas Hukum Universitas Bhayangkara Jakarta Raya, c). Kepulangan dan berpamitan dengan Kepala Sekolah dan seluruh jajaran SMAN 46 Jakarta, d). Penyusunan laporan pelaksanaan kegiatan pengabdian kepada masyarakat.

\section{Metode Pengukuran Capaian Hasil}

Guna mengetahui meningkatnya pemahaman siswa SMA akan cyberbullying dalam perspektif hukum pidana, pelaksana pengabdian kepada masyarakat menyebarkan angket/kuesioner dalam bentuk pre-test dan post-test. Dengan demikian, hasil yang diharapkan dapat tercapai dengan maksimal sebagaimana yang diharapkan.

Kegiatan pengabdian kepada masyarakat ditujukan kepada para siswa SMA, termasuk juga para mahasiswa yang hadir di lingkungan SMAN 46 Jakarta. Kegiatan penyuluhan tersebut dihadiri kurang lebih 33 siswa dan 10 mahasiswa, dengan harapan tingkat pemahaman siswa terhadap cyberbullying dalam perspektif hukum pidana dapat terealisasikan dengan baik. Tabel 1 menunjukkan harapan perubahan kondisi siswa dengan adanya penyuluhan tersebut.

Tabel 1. Harapan Perubahan Kondisi Sebelum dan Sesudah Program Pengabdian

\begin{tabular}{|c|c|c|c|}
\hline No & Unsur & Pra Pengabdian & Pasca Pengabdian \\
\hline 1 & 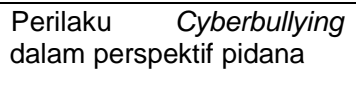 & $\begin{array}{l}\text { Belum memahami dan mengerti } \\
\text { aturan pidana mengenai } \\
\text { cyberbullying }\end{array}$ & $\begin{array}{l}\text { Sudah memahami dan mengerti } \\
\text { aturan pidana } \\
\text { cyberbullying }\end{array}$ \\
\hline 2 & $\begin{array}{l}\text { Hak dan kewajiban dari } \\
\text { korban dan pelaku tindak } \\
\text { pidana cyberbullying }\end{array}$ & $\begin{array}{l}\text { Belum memahami dan mengerti } \\
\text { Hak dan kewajiban dari korban } \\
\text { dan pelaku tindak pidana } \\
\text { Cyberbullying }\end{array}$ & $\begin{array}{l}\text { Sudah memahami dan mengerti Hak } \\
\text { dan kewajiban dari korban dan } \\
\text { pelaku tindak pidana Cyberbullying }\end{array}$ \\
\hline
\end{tabular}

Sumber: Hasil Pelaksanaan (2020) 


\section{Hasil dan Pembahasan}

Kegiatan penyuluhan hukum ini, sebagaimana disebutkan di atas, diikuti dari unsur siswa sebagai peserta utama dan para mahasiswa sebagai unsur peserta tambahan. Peserta utama diberikan materi sosialisasi tentang cyberbullying dalam perspektif hukum pidana, sehingga dapat meminimalisir perilaku yang mengarah kepada tindak pidana cyberbullying.

Kegiatan pengabdian kepada masyarakat dalam bentuk penyuluhan hukum sosialisasi tentang cyberbullying dalam perspektif hukum pidana secara umum berjalan dengan baik dan lancar. Kepala Sekolah beserta seluruh jajarannya ikut membantu dalam mempersiapkan segala kebutuhan kegiatan, mulai dari tempat, personel hingga mobilisasi siswa untuk ikut serta dalam kegiatan ini. Peserta kegiatan terdiri dari unsur siswa sebagai peserta utama dan para mahasiswa sebagai unsur peserta tambahan, bahkan ada juga dari beberapa guru yang hadir. Lokasi kegiatan bertempat di Aula SMAN 46 Jakarta Selatan yang sangat kondusif dan nyaman.

Kegiatan penyuluhan ini diawali dengan perkenalan tim pengabdi dengan siswa dan pihak sekolah yang hadir. Pengabdi terlebih dahulu memperkenalkan diri dilanjutkan dengan penyebaran kuesioner pre-test tentang cyberbullying dalam perspektif hukum pidana, guna mengetahui pengetahuan dasar peserta akan hal tersebut. Dalam kesempatan itu, Pengabdi dalam kegiatan Pengabdian Masyarakat Universitas Bhayangkara Jakarta Raya mengucapkan terima kasih atas penerimaan kegiatan ini dilanjutkan dengan sambutan Kepala Sekolah SMAN 46 Jakarta Selatan yang menyampaikan apresiasi dan dukungannya terhadap berlangsungnya kegiatan penyuluhan ini di sekolahnya sekaligus membuka kegiatan tersebut. Setelah itu, kegiatan dilanjutkan dengan pemaparan materi oleh pengabdi sebagai narasumber yang menyampaikan materi "Pemahaman Siswa SMA Tentang Cyberbullying Dalam Perspektif Hukum Pidana".

Selama kegiatan berlangsung, tampak peserta sangat antusias mendengarkan paparan materi penyuluhan. Pemparan materi berlangsung selama kurang lebih 40 menit dan dilanjutkan dengan sesi tanya jawab interaktif di akhir paparan. Antusiasme peserta dalam kegiatan ini terlihat dari pertanyaan-pertanyaan yang muncul untuk kemudian disampaikan jawabannya oleh pemateri.

Di penghujung kegiatan penyuluhan ini, pengabdi kembali menyebarkan kuesioner post-test untuk mengetahui sejauh mana tingkat pemahaman dan pertambahan pengetahuan siswa akan cyberbullying dalam perspektif hukum pidana.

Sebagai wujud apresiasi dari pengabdi, dilakukan penyerahan cinderamata dilanjutkan sesi foto bersama antara pengabdi, siswa, mahasiswa dan jajaran sekolah SMAN 46 Jakarta. Pelaksanaan penyuluhan dapat dilihat dalam pada gambar 2 .

Dari hasil penyuluhan, siswa dapat mengerti dan memahami ketentuan mengenai cyberbullying dalam perspektif hukum pidana dan cara untuk menghindarinya. Antusiasme siswa juga terlihat dari pertanyaan-pertanyaan yang muncul dalam sesi tanya jawab, antara lain: a). Terkait kasus mengenai cyberbullying, apakah pernah ada terjadi di Indonesia seorang 
remaja melakukan tindak tersebut? b). Bagaimana pengaturan mengenai pencemaran nama baik ataupun penghinaan melalui media elektronik? c). Apakah hal positif yang bisa diperoleh dari penggunaan media elektronik?
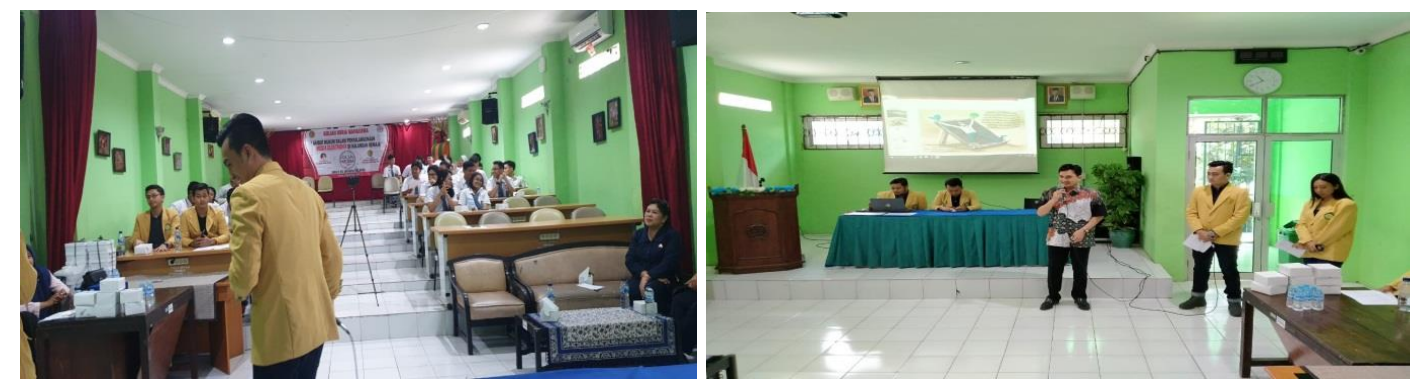

Sumber: Hasil Pelaksanaan (2020)

Gambar 2. Pelaksanaan Penyuluhan Tentang Cyberbullying Dalam Perspektif Hukum Pidana

Guna mengetahui tingkat keberhasilan kegiatan penyuluhan ini, para siswa peserta penyuluhan diberikan kuesioner. Pemberian kuesioner diberikan dalam dua tahap. Tahap pertama diberikan sebelum mereka mendapatkan materi tentang cyberbullying (pre-test). Tahap kedua diberikan setelah mereka mendengarkan sosialisasi tentang cyberbullying (post-test).

Pada tahap pre-test ini, setelah pengabdi menyebarkan kuesioner dan mengolah data jawaban dari siswa peserta penyuluhan, maka diperoleh hasil sebagaimana terlihat dalam Gambar 3.

\section{PEMAHAMAN SISWA SEBELUM MENDAPATKAN \\ PENYULUHAN TENTANG TINDAK PIDANA CYBERBULLYING}

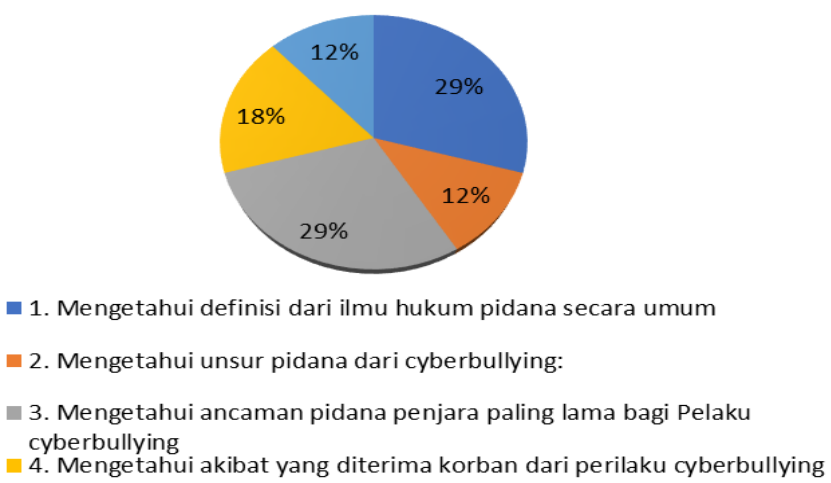

Sumber: Hasil Pelaksanaan (2020)

Gambar 3. Hasil Kuesioner Pre-Test

Keterangan Gambar 3 :

1) Sebanyak $29 \%$ siswa yang hadir dikegiatan penyuluhan mengetahui tentang definisi dari ilmu hukum pidana secara umum.

2) Sementara untuk pertanyaan tentang apakah siswa mengetahui unsur pidana dari cyberbullying, $12 \%$ menjawab mengetahui. 
3) Siswat menjawab pertanyaan tentang apakah mengetahui ancaman pidana penjara paling lama bagi Pelaku cyberbullying sekitar $29 \%$.

4) $18 \%$ siswa menjawab mengetahui akibat yang diterima korban dari perilaku cyberbullying.

5) Sementara untuk pertanyaan tentang mengetahaui tentang tindakan terhadap pelaku cyberbullying menjawab $12 \%$.

Pada tahap post-test ini, setelah pengabdi menyebarkan kuesioner dan mengolah data jawaban dari siswa peserta penyuluhan, maka diperoleh hasil sebagaimana terlihat dalam Gambar 4.

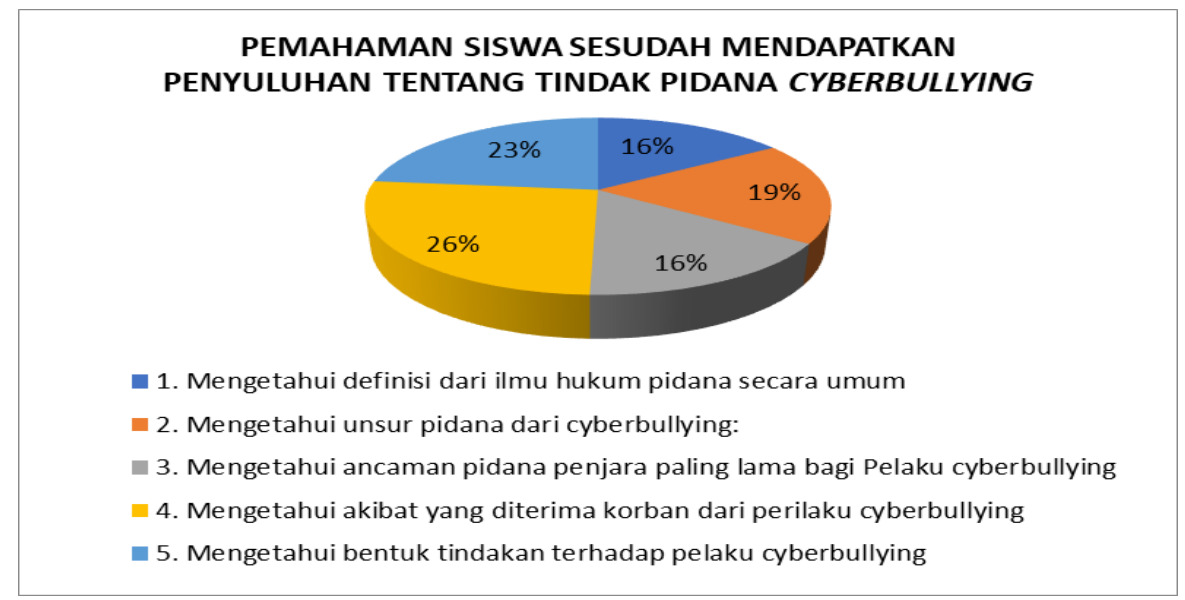

Sumber: Hasil Pelaksanaan (2020)

\section{Gambar 4. Hasil Kuesioner Post-Test}

Keterangan Gambar 4:

1) Sebanyak $16 \%$ siswa yang hadir dikegiatan penyuluhan mengetahui tentang definisi dari ilmu hukum pidana secara umum.

2) Sementara untuk pertanyaan tentang apakah siswa mengetahui unsur pidana dari cyberbullying, $19 \%$ menjawab mengetahui.

3) Siswa menjawab pertanyaan tentang apakah mengetahui ancaman pidana penjara paling lama bagi Pelaku cyberbullying sekitar $16 \%$.

4) $26 \%$ siswa menjawab mengetahui akibat yang diterima korban dari perilaku cyberbullying.

5) Sementara untuk pertanyaan tentang mengetahui tentang tindakan terhadap pelaku cyberbullying menjawab $23 \%$.

Jika dilihat dari Gambar 4 di atas, dapat ditarik kesimpulan akhir bahwa hasil peningkatan pengetahuan para siswa peserta penyuluhan tentang cyberbullying dalam perspektif hukum pidana adalah cukup signifikan.

Kegiatan pengabdian kepada masyarakat ini juga melibatkan Mahasiswa Fakultas Hukum Universitas Bhayangkara Jakarta Raya. Hal ini dimaksudkan agar para mahasiswa dapat ambil bagian dan terlibat langsung dalam hal mensosialisasikan perturan-peraturan yang 
berlaku. Di samping itu, pengalaman dan pengamalan ilmu dapat secara langsung mereka terapkan, sehingga kemajuan dalam bidang akademik akan jauh lebih terasa dimanapun para mahasiswa akan ikut mendalami materi-materi yang akan disampaikan.

\section{Kesimpulan}

Berdasarkan paparan di atas, dapat disimpulkan bahwa kegiatan pengabdian kepada masyarakat tentang cyberbullying dalam perspektif hukum pidana di SMAN 46 Jakarta telah terlaksana dengan baik dan lancar. Kegiatan pengabdian kepada masyarakat disambut respon positif dan respon yang sangat baik dari siswa peserta dilihat dari pertanyaan-pertanyaan yang muncul dalam kegiatan penyuluhan tersebut guna menjawab rasa keingintahuan mereka. Demikian juga adanya peningkatan pengetahuan dan pemahaman siswa peserta penyuluhan tentang cyberbullying dalam perspektif hukum pidana. Kegiatan pengabdian kepada masyarakat seperti penyuluhan hukum ini hendaknya dilakukan secara berkesinambungan baik di lokasi yang sama ataupun di lokasi yang berbeda dengan menyasar kepada siswa-siswa lain yang belum sepenuhnya paham akan cyberbullying dalam perspektif hukum pidana.

\section{Ucapan Terima Kasih}

Penulis mengucapkan terima kasih sebesar-besarnya kepada para peserta dari SMAN 46 Jakarta.

\section{Daftar Pustaka}

Kitab Undang-Undang Hukum Pidana.

Undang-Undang Nomor 19 Tahun 2016 Tentang Perubahan atas Undang-Undang Nomor 11 Tahun 2008 tentang Informasi dan Transaksi Elektronik.

Husak, D. (2008). Overcriminalization: The Limits of the Criminal Law, New York: Oxford University Press.

Juju, Dominikus dan Feri Sulianta. (2010). Hitam Putih Facebook, Jakarta: Elex Media Komputindo.

Kartono, K. (2013). Patologi Sosial 2 Kenakalan Remaja, Jakarta: PT Raja Grafindo Persada.

Roberts, A.R. dan Gilbert J. (2009). Buku Pintar Pekerja Sosial, Jakarta: BPK Gunung Mulia.

Smith, P.K., Mahdavi, J., Carvalho, M., Fisher, S., Russel, S., \& Tippet, N., (2008). Cyberbullying: Its Nature and Impact in Secondary School Pupils, Journal of Child Psychology and Psychiatry, 49.

Sunarto, K. (2012). Pengantar Sosiologi, Jakarta: Fak Ekonomi UI.

Widodo. (2013). Hukum Pidana di Bidang Teknologi Informasi Cybercrime Law, Telaah Teoritik dan Bedah Kasus, Yogyakarta: Aswaja Pressindo.

(Online 5 Juli 2013). Tersedia di www.hukumonline.com. "Banyak Remaja Indonesia jadi korban kejahatan di facebook," (Dilihat tanggal 9 Agustus 2019). 